\title{
Knowledge and awareness of ocular allergy among undergraduate students of public universities in Ghana
}

\author{
Samuel Kyei ${ }^{1 *}$, Bernard Tettey ${ }^{1}, K_{\text {Kofi Asiedu }}^{1,2}$ and Agnes Awuah ${ }^{1}$
}

\begin{abstract}
Background: Ocular allergy is a growing public health problem that greatly impacts the day-to-day life of sufferers and their families. Other aspects of their activities of daily living such as schooling, professional, and social life are affected hence an increased awareness and knowledge of ocular allergies, their detection and treatment is paramount. This study was to assess the level of knowledge and awareness of ocular allergy among undergraduate students of public universities in Ghana.

Methods: A descriptive cross sectional survey was conducted among 1000 students from three selected public universities in Ghana. Each respondent completed a questionnaire that had questions concerning awareness and knowledge of ocular allergy.

Results: Out of the 1000 students, 347 (34.7\%) were aware of ocular allergy. Of these 347 students, the level of knowledge of ocular allergy was generally low. Majority of the students had their source of information about ocular allergy from the media and the internet. There was statistical significant association among awareness of ocular allergy, sources of information and programme of study $(p<0.001)$.

Conclusion: Level of awareness among university students is generally low. Students' programmes of study influenced their knowledge of ocular allergy. Public health measures are recommended to help educate students on the prevention and control of ocular allergy as well as the complications associated with this condition.
\end{abstract}

Keywords: Conjunctivitis, Knowledge, Ocular allergy, Allergen, Assessment

\section{Background}

Ocular allergy also called allergic conjunctivitis represents a group of hypersensitivity disorders where the eyes produce an abnormal immunological response to normally harmless antigens (allergens) resulting in symptoms such as itching, tearing, burning, foreign-body sensation and ocular dryness. These symptoms of ocular allergy can begin at any age but children and young adults are the most susceptible. Allergies in general constitute the third most chronic disorder among children and ocular manifestation (allergic conjunctivitis) is the primary reason for pediatric eye consult [1-3]. The last four decades have actually seen an exponential increase in allergic diseases

\footnotetext{
*Correspondence: skyei@ucc.edu.gh

'Department of Optometry, School of Allied Health Sciences, College of Health and Allied Sciences, University of Cape-Coast, Cape-Coast, PMB, Ghana

Full list of author information is available at the end of the article
}

with about $15-20 \%$ of the world's population suffering ocular allergies alone [4-6]. It is reported that up to $40 \%$ of people of all age groups across the globe are affected by allergic diseases in its various forms [7]. A single reason for this upsurge in allergic diseases cannot be pinpointed. Experts are therefore contemplating the contribution of numerous factors, including genetics, air pollution, pets, and early childhood exposure [8]. Most of these factors are environmental resulting mainly from increasing industrialization [9].

In Ghana, the prevalence of allergic conjunctivitis from a hospital based study was found to be $9.1 \%$ (1718 out of 18,896 patients) [10]. However, other community based studies among school children indicated a higher prevalence of 17.3 and $39.9 \%$ respectively [11, 12]. Not only is it prevalent among children but several other studies have reported relatively higher prevalence than 
cataract and glaucoma among adults in Ghana [13, 14] yet it has not received the necessary attention accorded these other ocular disorders [15].

Other studies elsewhere in Hong Kong and France involving pediatric patients report that up to 30 and $32 \%$ of children with allergies respectively had ocular symptoms as the sole manifestation of their allergic disorder $[12,16,17]$. This makes ocular allergy one of the most common ocular diseases encountered in clinical practice, especially among children. Allergic disease involving the eye in the form of allergic rhinoconjunctivitis is not only common but a disease of public health concern due to its impact on quality of life and economic cost [18]. It is clearly evident that ocular allergy interferes with activities of daily living, particularly, academic, sleep, driving, extracurricular and other social activities of sufferers $[18,19]$.

The chronic forms of allergic diseases involving the eye (the lids, conjunctivae, and corneas) such as vernal keratoconjunctivitis (VKC), atopic keratoconjunctivitis (AKC), and giant papillary conjunctivitis (GPC) $[12,16]$ may necessitate co-management with allergists, dermatologists, and pediatricians. This poses a cost burden of specialists' consultation to sufferers [20]. For instance, the estimated cost burden in treating ocular allergy in the United States alone is approximately 5.9 billion dollars [21]. These chronic forms may also induce ocular surface tissue remodelling as there are no safe, longterm treatment regimens for severe forms of ocular allergic diseases.

However, pharmacological management is beset with challenges such as varying efficacy from patient to patient, drug cost, and potential complications such as dry eye, cataract and glaucoma [10]. This highlights the need for in-depth public health measures after careful assessment of the awareness and knowledge level of various populations. There is an urgent need to prioritize and concert research efforts in the field of ocular allergy. This will help in achieving sustainable results in prevention and control of this prevalent and chronic disease of the $21^{\text {st }}$ century [22]. This is even moreso, as the long term pharmacological treatment with steroids and antihistamines; the mainstay drugs used in Ghana have been linked with complications such as glaucoma, cataract and dry eye disease [10, 20, 23-25].

Various population-based studies have shown that awareness and knowledge of other eye diseases such as glaucoma and cataract among both rural and urban populations is low in developed countries and worse in developing countries [26-36]. Nevertheless, it is acknowledged that greater awareness of the allergic conjunctivitis and knowledge of treatment options will contribute immensely to the management of ocular allergy as a synergy to the effort of eye care practitioners [37]. Students in universities are better placed as agents of change in their communities and their knowledge of ocular allergy will not only impact their quality of life but their communities' at large and informed public health policies. This study therefore, sought to assess the knowledge and awareness of ocular allergy among university students in selected public universities in Ghana.

\section{Methods}

\section{Study design}

A descriptive cross-sectional study using a pre-tested semi-structured questionnaire was conducted among university students in three major public universities in Ghana. The questionnaire was designed based on a review of related studies [36, 38]. The questionnaire covered three main areas; demographic details, awareness and knowledge of ocular allergy. Awareness as used in this study was defined as 'having heard of ocular allergy' and consisted of several questions on basic national and international epidemiological facts aimed at establishing their awareness of ocular allergy. The questions about knowledge of ocular allergy centered on the definition of ocular allergy, signs and symptoms, common triggers of the disorder, as well as general treatment and management protocols.

\section{Data collection procedure and sampling technique}

The three universities out of the 8 public universities were conveniently selected in Ghana as these selected universities run the widest range of programmes and adequately represent students from all 10 political regions of the Country. These 3 institutions together had registered regular students (apart from those on distance learning) population of 87,224 at the time of the study. All these universities were organized into collegiate system. University of Ghana, (UG) structured into four colleges (Basic and Applied Sciences, Education, Health Sciences and Humanities) had a population of 29,754. Kwame Nkrumah University of Science and Technology, (KNUST) with six colleges (Agricultural and Natural Resources, Health Sciences, Art and Social Sciences, Architecture and Planning, Engineering, and Sciences) had 38,439 students. University of Cape Coast, (UCC) with five colleges (Agricultural and Natural Sciences, Distance Education, Education Studies, Humanity and Legal Studies, Health and Allied Sciences) had 19,031 students. A total of 1300 questionnaires were proportionately allotted to these 3 universities according to their population sizes. UG was allotted 443, KNUST; 573 and UCC; 284 of the questionnaires. Based on the assumptions that students were evenly distributed across the various colleges, the allotted questionnaires to each university were equally assigned to the colleges of the universities. A list of students in each college was then obtained from the colleges' registry and 
every $50^{\text {th }}$ student was selected. The selected students were approached with addressed questionnaires by a team of trained research assistants. The teams of assistants were recruited from each university campus as they were familiar with the terrain on their respective campuses. The data collection lasted for a period of 3 months. The retrieved completed questionnaires were then sorted for each university and the following groupings were derived: Sciences (biological, physical, mathematical, agricultural, engineering sciences, etc.); Arts, Social Sciences and Law; Education; Business (Accounting, management, commerce, business administration, etc); and Health Sciences (medicine, optometry, dentistry nursing, pharmacy, physiotherapy, medical laboratory technology, herbal medicine, veterinary medicine, etc.).

\section{Data analysis}

The data obtained were entered into the Statistical Product and Service Solutions (SPSS version 21). The same tool was used for data analysis. Descriptive statistics, frequency tables and percentages were used in the data analysis and interpretation. The relationship between awareness of ocular allergy and demographic factors such as age, gender, level, and programme of study was assessed using the chisquare test. A $p$-value of less than 0.05 was considered statistically significant.

\section{Results}

\section{Demographic characteristics}

Twenty questionnaires were pretested among 20 nonoptometry students for the corrections of ambiguities and minimization of medical jargons. The questionnaire was then modified and pretested again among 50 non health science students for further revision and adjustment before final field administration. Of the 1300 questionnaires that were distributed, 1000 completed questionnaires were retrieved, giving an overall response rate of $76.9 \%$. The details with respect to the 3 universities are as follows: UG (341 out of 443, $77.0 \%$ ), KNUST (441 out of $573,71.7 \%)$ and UCC (218 out of 284, $76.8 \%)$. The respondents included 605 males (60.5\%). Their ages ranged from 17 to 40 years with a mean age of $22 \pm$ 2.32 years (Table 1 ).

\section{Awareness of ocular allergy}

Out of the 1000 participants, only 347 were aware of ocular allergy as per the operational definition, citing varying sources as "where they heard about ocular allergy". These sources were: medical training, media, internet, a relative or friend and from an eye care practitioner. The media was the source of awareness and knowledge among $82(23.6 \%)$ of the participants. The next major source of information about ocular allergy
Table 1 Demographic characteristics

\begin{tabular}{lllll}
\hline Gender & Male & Female & Total & \\
& $605(60.5 \%)$ & $395(39.5 \%)$ & 1000 & \\
Age & $17-25$ years & Above 25 years & Total & \\
& $949(94.9 \%)$ & $51(5.1 \%)$ & 1000 & \\
Programmes & UG & KNUST & UCC & Total \\
Sciences & 65 & 146 & 27 & 238 \\
Arts & 134 & 124 & 32 & 290 \\
Education & - & - & 100 & 100 \\
Business & 60 & 55 & 34 & 149 \\
Health Sciences & 82 & 116 & 25 & 223 \\
\hline
\end{tabular}

was the internet which was the source of $81(23.3 \%)$ of the respondents. Fifty eight $(16.7 \%)$ participants acquired their awareness and knowledge from their medical training. This was same $(n=58,16.7 \%)$ for respondents whose source of awareness and knowledge was from Eye care practitioners. Two hundred and eight (59.9\%) respondents (out of the 347 ) knew that millions of people worldwide are affected by ocular allergies each year while $61.4 \%$ were aware that ocular allergy could lead to visual loss. Only $32.0 \%$ were aware of the fact that about forty percent of Ghanaians suffer from ocular allergy. Out of the 347 respondents, 152 (43.8 \%) were not aware that Ocular allergy is one of the most common eye conditions encountered by eye care professionals as well as General practitioners. However, only $85.9 \%$ of the respondents were aware of itching, as a primary source of discomfort among those who suffer ocular allergies. An association was found between the institution and awareness of ocular allergy $\left(\chi^{2}=16.130\right.$, $\mathrm{df}=2, p<0.001)$. Again, an association was found between the programme of study and the awareness of ocular allergy $\left(\chi^{2}=112.372, \mathrm{df}=4, p<0.001\right)$. This is shown in Table 2.

\section{Knowledge of ocular allergy}

Out of the 347 respondents who were aware, 194 representing $55.9 \%$ defined ocular allergy as inflammation of the eye in response to a non-infectious or harmless foreign agent entering the eye. Sixty-six respondents, representing $19.0 \%$ defined ocular allergy as discomfort and pains within the eye. Fifty-five respondents, representing $15.9 \%$ defined ocular allergy as an eye condition caused by frequent rubbing of the eye. Thirty-two (9.2\%) did not know what ocular allergy was. Out of the 347 respondents, 39 (11.2\%) participants believed that ocular allergy affects the conjunctiva only. Twenty -two (6.3\%) participants believed that ocular allergy affects the cornea only. One hundred (22.8\%) respondents knew that ocular allergy affects the conjunctiva, cornea and eyelids, while $64(18.4 \%)$ respondents knew that 
Table 2 Awareness of Ocular Allergy

\begin{tabular}{|c|c|c|c|c|c|c|c|}
\hline \multirow[b]{2}{*}{ Parameter } & \multicolumn{6}{|c|}{ Programme of study } & \multirow[b]{2}{*}{ Total } \\
\hline & & Science & Humanities & Education & Business & Health sciences & \\
\hline \multirow[t]{6}{*}{ What is your source of information } & Media & $25(26.6)$ & $28(27.5)$ & $9(47.4)$ & $5(29.4)$ & $15(13.0)$ & $82(23.6)$ \\
\hline & Internet & $22(23.4)$ & $26(25.3)$ & $3(15.8)$ & $5(29.4)$ & $25(21.7)$ & $81(23.3)$ \\
\hline & Friends/relatives & $17(18.1)$ & $17(16.7)$ & $2(10.5)$ & $4(23.5)$ & $14(12.2)$ & $54(15.6)$ \\
\hline & Eye specialist & $13(13.8)$ & $14(13.7)$ & $3(15.8)$ & $3(17.6)$ & $25(13.0)$ & $58(16.7)$ \\
\hline & Program training & $13(13.8)$ & $11(10.8)$ & $2(10.5)$ & 0 & $32(27.8)$ & $58(16.7)$ \\
\hline & Others & $4(4.3)$ & $6(5.9)$ & 0 & 0 & $4(3.5)$ & $14(4.0)$ \\
\hline \multirow{3}{*}{$\begin{array}{l}\text { In your opinion does ocular allergy } \\
\text { affect millions of people worldwide } \\
\text { each year? }\end{array}$} & No & $8(8.5)$ & $9(8.8)$ & $1(5.3)$ & $1(5.9)$ & $11(9.6)$ & $30(8.6)$ \\
\hline & Yes & $64(68.1)$ & $61(59.8)$ & $11(57.9)$ & $10(58.8)$ & $62(53.9)$ & $208(59.9)$ \\
\hline & Don't know & $22(24.4)$ & $32(31.4)$ & $7(36.8)$ & $6(35.3)$ & $40(34.8)$ & $107(30.8)$ \\
\hline \multirow{3}{*}{$\begin{array}{l}\text { About forty percent of the Ghanaian } \\
\text { population suffers from ocular allergy }\end{array}$} & True & $34(36.2)$ & $35(34.3)$ & $5(26.3)$ & $7(41.2)$ & $30(26.1)$ & $111(32.0)$ \\
\hline & False & $7(7.4)$ & $6(5.9)$ & $3(15.8)$ & $1(5.9)$ & $8(7.0)$ & $25(7.2)$ \\
\hline & Don't know & $53(56.4)$ & $51(50.0)$ & $11(57.9)$ & $9(52.9)$ & $77(67.0)$ & $211(60.8)$ \\
\hline \multirow[t]{3}{*}{ Could ocular allergy lead to visual loss? } & No & $19(20.2)$ & $13(12.7)$ & $3(15.8)$ & $3(17.6)$ & $23(20.0)$ & $61(17.6)$ \\
\hline & Yes & $62(66.0)$ & $69(67.6)$ & $14(73.7)$ & $13(76.5)$ & $55(47.8)$ & $213(61.4)$ \\
\hline & Don't know & $13(13.8)$ & $20(19.6)$ & $2(10.5)$ & $19(5.9)$ & $37(32.2)$ & $73(21.0)$ \\
\hline \multirow{3}{*}{$\begin{array}{l}\text { Ocular allergy is one of the most common } \\
\text { eye conditions encountered by General } \\
\text { Practitioners as well as eye care practitioners }\end{array}$} & True & $55(58.5)$ & $51(50.0)$ & $7(36.8)$ & $8(47.1)$ & $74(64.3)$ & $195(56.2)$ \\
\hline & False & $6(6.4)$ & $6(5.9)$ & 0 & $19(5.9)$ & $14(12.2)$ & $27(7.8)$ \\
\hline & Don't know & $33(35.1)$ & $45(44.1)$ & $12(63.2)$ & $8(47.1)$ & $27(23.5)$ & $125(36.0)$ \\
\hline \multirow{3}{*}{$\begin{array}{l}\text { Majority of people who have ocular allergy } \\
\text { experience itching as the primary source of } \\
\text { discomfort }\end{array}$} & True & $84(89.4)$ & $80(78.4)$ & $13(68.4)$ & $13(76.5)$ & $108(93.9)$ & 298 (85.9) \\
\hline & False & $3(3.2)$ & $6(5.9)$ & $1(5.3)$ & $2(11.8)$ & $1(0.1)$ & $13(3.7)$ \\
\hline & Don't know & $7(7.4)$ & $16(15.7)$ & $5(26.3)$ & $2(11.8)$ & $6(5.2)$ & $36(10.4)$ \\
\hline
\end{tabular}

ocular allergy affects the conjunctiva, cornea, limbus, and eyelids. However, 122 (35.2 \%) did not know the eye structures involved in ocular allergy (Table 3).

Out of the 347 respondents, $300(86.5 \%)$ respondents recognized 'itching' as a symptom, 277 (79.8 \%) respondents identified 'redness' as a sign, while 153 (44.1\%) respondents recognized 'discharge' as a sign. One hundred and eighty-one (52.2\%) respondents ticked 'tearing' as a symptom, 91 (26.2 \%) recognized 'photophobia' as a symptom while 147 (42.4\%) respondents identified 'blurred vision' as a symptom of ocular allergy. Two hundred and forty-one $(69.5 \%)$ respondents knew that 'headache' is not a symptom of ocular allergy while 294 $(84.7 \%)$ respondents were able to recognize that 'nausea' is not a symptom (Table 4). Out of the 347 respondents, only $97(28.0 \%)$ respondents recognized 'seasonal allergic conjunctivitis' as a form of ocular allergy, 43 $(12.4 .8 \%)$ respondents identified 'perennial allergic conjunctivitis' as a form, while 50 (14.4 \%) respondents recognized 'vernal conjunctivitis' as a form of ocular allergy. Twenty-eight $(8.1 \%)$ respondents ticked 'giant papillary conjunctivitis' as a form, and 38 (11.0\%) respondents recognized 'atopic keratoconjunctivitis' as a form of ocular allergy. Seventy-eight $(22.5 \%)$ respondents knew that 'bacterial conjunctivitis' is not a form of ocular allergy while 117 (33.7\%) respondents were able to recognize that 'viral conjunctivitis' is not a form of ocular allergy (Table 5).

Thirty-five respondents, representing $10.1 \%$ indicated that best way of preventing ocular allergy is to apply anti-allergic medication. Eleven respondents, representing $3.2 \%$ said that staying away from those having ocular allergy was the best way to prevent ocular allergy. One hundred and ninety-four respondents, representing $55.9 \%$ knew that avoiding the source of allergy triggers was the best way to prevent ocular allergy. Seventy-three $(21.0 \%)$ responded that the best way of preventing ocular allergy is to visit eye clinics. Thirty-three $(9.5 \%)$ did not know how ocular allergies could be prevented. Out of the 347 participants, 146 (42.1\%) knew of substances which trigger allergic response in the eye while 201 (57.9 \%) did not know of substances which trigger allergic response in the eye. Respondents who knew of ocular allergy triggers were made to specify them. Multiple responses were allowed since the question was an open-ended one and 74 out 347 respondents representing $21.3 \%$ could mention at least one drug used in management of ocular allergy. The remaining 273 participants representing $78.7 \%$ had no knowledge of drugs used in managing ocular allergy. 
Table 3 Knowledge of ocular allergy

\begin{tabular}{|c|c|c|c|c|c|c|c|}
\hline \multirow[b]{2}{*}{ Parameter } & \multicolumn{6}{|l|}{ Programme of study } & \multirow[b]{2}{*}{ Total } \\
\hline & & Science & Humanities & Education & Business & Health sciences & \\
\hline \multirow[t]{4}{*}{$\begin{array}{l}\text { What is your understanding of } \\
\text { ocular allergy? }\end{array}$} & $\begin{array}{l}\text { Caused by frequent rubbing } \\
\text { of the eye }\end{array}$ & $19(20.2)$ & $17(16.7)$ & $6(31.6)$ & $5(29.4)$ & $8(7.0)$ & $55(15.8)$ \\
\hline & $\begin{array}{l}\text { Inflammation of the eye in } \\
\text { response to harmless foreign } \\
\text { substance }\end{array}$ & $46(48.9)$ & $48(47.1)$ & $7(36.8)$ & $4(23.5)$ & $89(77.4)$ & $194(55.9)$ \\
\hline & $\begin{array}{l}\text { Discomfort and pains within } \\
\text { the eye }\end{array}$ & $23(24.5)$ & $24(23.5)$ & $2(10.5)$ & $4(23.5)$ & $13(11.3)$ & $66(19.0)$ \\
\hline & Don't know & $6(6.4)$ & $13(12.7)$ & $4(21.1)$ & $4(23.5)$ & $5(4.3)$ & $32(9.2)$ \\
\hline \multirow{5}{*}{$\begin{array}{l}\text { Eye structures involved in } \\
\text { ocular allergy include }\end{array}$} & Conjunctiva & $11(11.7)$ & $12(11.7)$ & $3(15.80$ & $3(17.6)$ & $10(8.7)$ & $39(11.2)$ \\
\hline & Cornea & $10(10.6)$ & $3(2.9)$ & $4(21.1)$ & $2(11.8)$ & $3(2.6)$ & $22(6.3)$ \\
\hline & Conjunctiva, cornea, eyelid & $25(26.6)$ & $21(20.6)$ & 0 & $6(35.3)$ & $48(41.7)$ & $100(28.8)$ \\
\hline & Conjunctiva, cornea, limbus,eyelid & $13(13.8)$ & $15(14.7)$ & $1(5.3)$ & $2(11.8)$ & $33(28.7)$ & $64(18.4)$ \\
\hline & Don't know & $35(37.2)$ & $51(50.0)$ & $11(57.9)$ & $4(23.5)$ & $21(18.30$ & $122(35.2)$ \\
\hline \multirow{3}{*}{$\begin{array}{l}\text { Are ocular allergies transmitted } \\
\text { from person to person? }\end{array}$} & Yes & $64(68.1)$ & $55(53.9)$ & $8(42.1)$ & $11(64.7)$ & $77(67.0)$ & $215(62.0)$ \\
\hline & No & $8(8.5)$ & $10(9.8)$ & $1(5.3)$ & $19(5.9)$ & $11(9.6)$ & $31(8.9)$ \\
\hline & Don't know & $21(22.3)$ & $37(36.3)$ & $10(52.6)$ & $5(29.4)$ & $27(23.5)$ & $100(28.8)$ \\
\hline \multirow{5}{*}{$\begin{array}{l}\text { What is the best way to prevent } \\
\text { ocular allergy? }\end{array}$} & Apply anti- allergic drugs & $6(6.4)$ & $9(8.8)$ & $2(10.5)$ & $5(29.4)$ & $13(11.3)$ & $35(10.1)$ \\
\hline & $\begin{array}{l}\text { Stay away from those with } \\
\text { the disease }\end{array}$ & $1(1.1)$ & $4(3.9)$ & $1(5.3)$ & 0 & $5(4.3)$ & $11(3.2)$ \\
\hline & Avoid the source of trigerrs & $52(55.3)$ & $47(46.1)$ & $6(31.6)$ & $6(35.3)$ & $83(72.2)$ & $194(55.9)$ \\
\hline & Visit eye clinics & $24(25.5)$ & $30(29.4)$ & $7(36.8)$ & $4(23.5)$ & $8(7.0)$ & $73(21.0)$ \\
\hline & Don't know & $11(11.7)$ & $12(11.7)$ & $3(15.8)$ & $2(11.8)$ & $5(4.3)$ & $33(9.5)$ \\
\hline \multirow{2}{*}{$\begin{array}{l}\text { Do you know substances that } \\
\text { trigger allergies in the eye? }\end{array}$} & No & $52(55.3)$ & $69(67.6)$ & $15(78.9)$ & $11(64.7)$ & $54(47.0)$ & $201(57.9)$ \\
\hline & yes & $42(44.7)$ & $33(32.4)$ & $4(21.1)$ & $6(35.3)$ & $61(53.0)$ & $146(42.1)$ \\
\hline \multirow{2}{*}{$\begin{array}{l}\text { Do you know of medications } \\
\text { used for treating ocular allergy? }\end{array}$} & No & 77 (81.9) & $86(84.3)$ & $17(89.5)$ & $14(82.4)$ & $79(68.7)$ & $273(78.7)$ \\
\hline & yes & $17(18.1)$ & $16(15.7)$ & $2(10.5)$ & $3(17.6)$ & $36(31.3)$ & $74(21.3)$ \\
\hline \multirow[t]{3}{*}{ Some eye allergies are inherited } & True & $44(46.8)$ & $57(55.9)$ & $11(57.9)$ & $10(58.8)$ & $46(40.0)$ & $168(48.4)$ \\
\hline & False & $13(13.8)$ & $12(11.7)$ & $3(15.8)$ & $1(5.9)$ & $19(16.5)$ & $48(13.8)$ \\
\hline & Don't know & $37(39.4)$ & $33(32.3)$ & $5(26.3)$ & $6(35.3)$ & $50(43.5)$ & $131(37.8)$ \\
\hline \multirow{3}{*}{$\begin{array}{l}\text { Smoking is a risk factor for } \\
\text { ocular allergy }\end{array}$} & True & $49(52.1)$ & $48(47.1)$ & $10(52.6)$ & $11(64.7)$ & $54(47.0)$ & $172(49.6)$ \\
\hline & False & $8(8.5)$ & $7(6.9)$ & 0 & $1(5.9)$ & $11(9.6)$ & $27(7.8)$ \\
\hline & Don't know & $37(39.4)$ & $47(48.0)$ & $9(47.40$ & $5(29.4)$ & $50(43.5)$ & $148(42.7)$ \\
\hline
\end{tabular}

Table 4 Knowledge of signs and symptoms of ocular allergy

\begin{tabular}{llll}
\hline & \multicolumn{3}{l}{ Frequency (Percentages) } \\
\cline { 2 - 4 } Signs and symptoms & $277(79.8)$ & $43(12.4)$ & $27(7.8)$ \\
\hline Redness & $5(21.6)$ & $241(69.5)$ & $31(8.9)$ \\
Headache & $300(86.5)$ & $21(6.1)$ & $26(7.5)$ \\
Itching & $18(5.2)$ & $294(84.7)$ & $35(10.1)$ \\
Nausea & $153(44.1)$ & $163(46.9)$ & $31(9.0)$ \\
Discharge & $147(42.4)$ & $167(48.1)$ & $33(9.5)$ \\
Blurred vision & $91(26.2)$ & $224(64.6)$ & $32(9.2)$ \\
Photophobia & $181(52.2)$ & $136(39.2)$ & $30(8.6)$ \\
Tearing & & &
\end{tabular}

Table 5 Knowledge of the forms of ocular allergy

\begin{tabular}{llll}
\hline Forms of ocular allergy & \multicolumn{3}{l}{ Frequency (percentages) } \\
\cline { 2 - 4 } & Yes & No & Don't know \\
\hline Bacterial conjunctivitis & $102(29.4)$ & $78(22.5)$ & $167(48.1)$ \\
Seasonal conjunctivitis & $97(28.0)$ & $83(23.9)$ & $167(48.1)$ \\
Viral conjunctivitis & $61(17.6)$ & $117(33.7)$ & $169(48.7)$ \\
Giant papillary & $28(8.1)$ & $150(43.2)$ & $169(48.7)$ \\
Vernal conjunctivitis & $50(14.4)$ & $130(37.5)$ & $167(48.1)$ \\
Perennial conjunctivitis & $43(12.4)$ & $136(39.2)$ & $168(48.4)$ \\
Atopic keratoconjunctivitis & $38(11.0)$ & $140(40.3)$ & $169(48.7)$ \\
\hline
\end{tabular}


Out of the 347 participants, 31 (8.9) respondents indicated that ocular allergy is transmitted from one person to another; 215 respondents knew that ocular allergy is not transmitted from person to person and 101 (29.1) respondents had no knowledge about it. Also 168 (48.4\%) said that ocular allergies are inherited, while 48 $(13.8 \%)$ said this assertion was false. One hundred and thirty-one respondents representing $37.8 \%$ did not know whether this assertion was true or false. Again, $172(49.6 \%)$ said that smoking is a risk factor for ocular allergy while 27 (7.8 \%) said the assertion was false. One hundred and forty-eight respondents representing $42.7 \%$ did not know whether this assertion was true or false (Table 3).

\section{Discussion}

\section{Awareness of ocular allergy}

The study was based on the assumptions that students were evenly distributed across the colleges which could affect the representativeness of the various constituents of the universities. The questionnaire used has the limitation of ascertaining the truthfulness of responses provided. Nevertheless, the large size of the study sample has the benefit of mitigating these limitations to some extent.

The awareness level of ocular allergy among students at the tertiary level was relatively low. Ocular allergy is not considered a top priority eye disease and has not received adequate public health attention despite its noisome symptoms and complications [39]. This could have accounted for the low awareness level. Besides this, reports regarding awareness of some of the priority eye diseases such as glaucoma and cataract have been found to be low, raising concern for intense public education [26-36]. Similarly, another study found generally low awareness level among patients with respect some emergent ophthalmic diseases such as retinal detachment, acute angle-closure glaucoma, giant cell arteritis, and central retinal artery occlusion [40]. This obviously has implication for early medical presentation and maximization of visual prognosis. Awareness level of eye diseases is generally low compared to sexually transmitted infections, STIs and coronary heart diseases [41, 42].

It is worthy to note that half of students (51.6\%) who were aware of ocular allergy were from the health sciences indicating the extent of ignorance among the educated non health science students. The health science students heard of ocular allergy mainly through their medical training as well as contact with eye care providers most of whom are involved with their training. This presupposes that public education on ocular allergy is either non-existing or rudimentary among university students in Ghana. Programme of study, and for that matter area of specialty, was therefore a useful predictor of awareness of ocular allergy.

\section{Knowledge of ocular allergy}

Out of the 347 participants who were aware of ocular allergy, more than half $(55.9 \%)$ could correctly define ocular allergy as inflammation of the eye in response to a non-infectious or when a harmless foreign agent make contact with the eye. Such students were mainly from the health sciences $(45.9 \%)$ and the sciences $(23.7 \%)$. Some $44.1 \%$ from education, business and arts did not know the definition for ocular allergy. Thus health science students had the advantage of having good knowledge about ocular allergy over the non-health science students.

The findings of this study indicate that itching (86.5\%) was the most recognized symptom of ocular allergy among the respondents who were aware of the condition unlike the reported poor knowledge of symptoms of giant cell arteritis, and central retinal artery occlusion [40]. Itching is typical of ocular allergy and diagnosis without the symptom of ocular itch is always problematic [10, 15, 21]. Studies have shown that bothersome nature of ocular itch is a major drive for the practice of ocular self medication not only among university students [43] but the general population [44]. Photophobia (26.2 \%) was the least recognized symptom of ocular allergy as it associated with several other ocular diseases other than allergy [45]. In the study, more than half $(57.9 \%)$ did not know of agents which trigger allergic response in the eye. This underscore the essence of public health education since knowledge of allergy triggers is key to the prevention and control of ocular allergy $[38,46]$. However, more than half $(55.9 \%)$ knew that avoiding the source of allergy triggers was the best way to prevent ocular allergy. Avoidance of allergens is the ideal non-pharmacological approach to the control and prevention of allergic eye disease despite the challenges it poses due to the lack of awareness on the distributions and density of these widespread triggers among the populace [20]. Most of the students who knew this acquired their source from medical training, eye care professionals and the internet. Dust was the most recognized trigger of ocular allergy followed by pollen, smoke and pet dander respectively. These allergens identified by the respondents have been found to be common in the tropics and have particularities of interest as they provide clues to improved understanding of the pathogenesis, diagnosis and management of allergic diseases in the Tropics [47].

Out of the 347 respondents who were aware of the disorder, less than one-quarter $(21.3 \%)$ could mention at least one drug used in management of ocular allergy, the remaining 273 three-quarters $(78.7 \%)$ had no knowledge of drugs used in managing ocular allergy given the fact that most of these ophthalmic preparations for allergy are sold over the counter. This presupposes that they are unlikely not to risk self medication or advice 
pharmacological intervention in case ocular allergy since they have little knowledge. However, should they risk the use of this option it could lead to all sort of adverse reactions as a result of their unformed actions or inactions [48].

\section{Source of awareness and knowledge about ocular allergy}

In this study, majority of the respondents acquired their knowledge of ocular allergy through the media and the internet. Medical training and information from eye care providers played the second major role in creating awareness of among $33.4 \%$ of the 347 respondents. Information from relatives or friends on ocular allergy contributed similarly to awareness creation. This highlights the need for an informed community capable of the provision of timely basic education at the primary care level. There was a statistically significant association between the programme of study and the source of information, which is consistent with other studies among hospital workers where different workers with different area specialty had had different sources of information [35]. It can be deduced from the study that the media was the major source of information among the arts, education and business and science students. Respondents who had their knowledge of ocular allergy through medical training as well as eye care providers tended to have more knowledge than those who chose media and internet as their main source of information. There was a lag in knowledge of ocular allergy acquired from the media compared to that acquired during the course of medical training. Thus though the media was the leading source in terms of ocular allergy awareness creation, people who chose the media demonstrated the weakest level of knowledge about ocular allergy. It is not clear exactly what the media conveys to the general public about ocular allergy. This gives a clue that perhaps there is a lot of public misinformation about diseases from the media. It is questionable which resource persons' champion the course of public education through the media as this seems to the trend in other awareness and knowledge studies [41, 49].

\section{Conclusions}

From the study, it can be concluded that the level of awareness of ocular allergy was relatively low among university students and far lower when students from the health sciences were excluded. Though the media was the leading source in terms of awareness creation, students who had their source from the media had the weakest level of knowledge of ocular allergy. Students who had their knowledge through medical training and eye care providers demonstrated the highest level of knowledge of ocular allergy.
Therefore extra effort should be made by relevant stakeholders in creating awareness in order to reduce the impact of ocular allergy on the quality of life of students and their potential complications.

\section{Abbreviations}

AKC: Atopic keratoconjunctivitis; GPC: Giant papillary conjunctivitis; KNUST: Kwame Nkrumah University of Science and Technology; SPSS: Statistical product and service solutions; UCC: University of Cape Coast; UG: University of Ghana; VKC: Vernal keratoconjunctivitis

\section{Acknowledgements \\ The authors are grateful to research assistants from various institutions who assisted in the data collection. Special thanks to Mrs Esther Kyei, Mrs Agnes Asiedu, Mr. Jacob Gaddah and Mr. Ebenezer Okor for their immense support and encouragement.}

Funding

There was no funding for this study.

\section{Availability of data and materials}

The datasets used and /or analysed during the current studyavailable from the corresponding author on reasonable request.

\section{Authors' contributions}

SK conceived the idea and designed the study. BT wrote the protocol, managed the literature searches, collected data, and wrote the first draft of the manuscript. KA managed the analyses. AA, KA, SK were involved in the design of the study and interpretation of the data. SK, BT, KA and AA critically revised the content. All authors read and approved the final manuscript.

\section{Authors' information}

SK holds Doctor of Optometry degree from University of Cape Coast, Ghana; Master of Philosophy in Pharmacology from Nkrumah University of Science and Technology, Ghana. SK holds a PhD in Optometry from University of KwaZulu Natal, South Africa. SK is a lecturer at the Department of Optometry and School's registration officer, School of Allied Health Sciences, University of Cape Coast. BT is a graduate of Optometry from University of Cape Coast, Ghana and an intern Optometrist at Watborg Eye Services, Kasoa, Ghana. KA holds Doctor of Optometry from University of Cape Coast. KA is a consulting optometrist at St. Thomas Eye hospital but at the time of the study KA was an intern Optometrist at Komfo Anokye Teaching hospital, Ghana. AA is a consulting Optometrist and a Principal Research Assistant at Department of Optometry, University of Cape Coast, Ghana.

Competing interests

The authors declare that they have no competing interests.

\section{Consent for publication}

Not applicable.

\section{Ethics approval and consent to participate}

The study was approved by University of Cape Coast Institutional Review Board (Reference number: UCCIRB/CHAS/2015/056). In addition participants signed a written informed consent form which outlined the purpose of the study its merits and demerits. Anonymity of respondents as well as confidentiality of information provided was ensured. Students were also informed that the research participation was voluntary and not mandatory, and that meant they could choose to withdraw their participation at any stage. The study was conducted in accordance with the tenet of the Helsinki declaration regarding the use of human subject in research.

\section{Author details}

'Department of Optometry, School of Allied Health Sciences, College of Health and Allied Sciences, University of Cape-Coast, Cape-Coast, PMB, Ghana. ${ }^{2}$ Refraction and Low Vision Clinic, Eye Center, Komfo Anokye Teaching Hospital, P. O Box 1934, Kumasi, Ghana. 
Received: 20 July 2016 Accepted: 20 October 2016 Published online: 28 October 2016

\section{References}

1. National Academy on an Aging Society. Chronic conditions: A challenge for the 21 st century. 2000

2. American College of Allergy, Asthma, and Immunology. Allergy Facts. www. acaai.org/news/facts-statistics/allergies. Accessed 29 Sept 2016.

3. Fauquert $\mathrm{J}$. Childhood allergic conjunctivitis: the allergist's point of view. J Fr Ophthalmol. 2007;30:292-9.

4. Barbee RA, Kaltenborn W, Lebowitz MD, Burrows B. Longitudinal changes in allergen skin test reactivity in a community population sample. J Allergy Clin Immunol. 1987;79:16-24

5. Maziak W, Behrens T, Brasky TM, Duhme H, Rzehak P, Weiland SK, Keil U. Are asthma and allergies in children and adolescents increasing. Results from ISAAC phase I and phase III surveys in Munster, Germany. Allergy. 2003;58:572-9.

6. Verlato G, Corsico A, Villani S, Cerveri I, Migliore E, Accordini S, et al. Is the prevalence of adult asthma and allergic rhinitis still increasing? Results of an Italian study. J Allergy Clin Immunol. 2003;111:1232-8.

7. Singh K, Bielory L. Epidemiology of ocular allergy symptoms in United States adults (1988-1994). American College of Allergy, Asthma \& Immunology Annual Meeting; Nov 9-15, 2006; Philadelphia, PA. Abstract 34.

8. Bielory L. Allergic and immunologic disorders of the eye. Part II: ocular allergy. J Allergy Clin Immunol. 2000;106:1010-32.

9. Bielory L, Meltzer EO, Nichols KK, Melton R, Thomas RK, Bartlett JD. An algorithm for the management of allergic conjunctivitis. Allerg Asthma Proc. 2013;34:408-20.

10. Abokyi S, Koffuor GA, Ntodie M, Kyei S, Gyanfosu L. Epidemiological profile and pharmacological management of allergic conjunctivitis: A study in Ghana. Int J Pharm Biomed Res. 2012;3:195-201.

11. Nartey ET, van Staden DB, Amedo AO. Prevalence of Ocular Anomalies among Schoolchildren in Ashaiman, Ghana. Optom Vis Sci. 2016:93:607-11.

12. Kumah DB, Lartey SY, Yemanyi F, Boateng EG, Awuah E. Prevalence of allergic conjunctivitis among basic school children in the Kumasi metropolis (Ghana): a community based cross-sectional study. BMC Ophthalmol. 2015:15:69.

13. Tanle A, llechie AA, Awusabo-Asare K, Ovenseri GO, Anderson M. Ocular conditions among women involved in palm kernel oil processing in the Cape Coast Metropolis, Ghana. SBHA. 2011;76:25-40.

14. Ovenseri-Ogbomo G, Ocansey S, Abu E, Kyei S, Boadi-Kusi S. Oculo-Visual Findings among Industrial Mine Workers at Goldfields Ghana Limited, Tarkwa. Ophthalmol Eye Dis. 2012;30:35-42.

15. Rosario N, Bielory L. Epidemiology of allergic conjunctivitis. Curr Opin Allergy Clin Immunol. 2011;11:471-6.

16. Bielory L. Update on ocular allergy treatment. Expert Opin Pharmacother. 2002:3:541-53

17. Y-L LD. A practical approach to management of allergic eye conditions in Children. J Paediatr Respir Crit Care. 2010;6:5-10.

18. La Rosa M, Lionetti E, Reibaldi M, Russo A, Longo A, Leonardi S, et al. Allergic conjunctivitis: a comprehensive review of the literature. Ital J Pediatr. 2013:39:18

19. Pitt AD, Smith AF, Lindsell L, Voon LW, Rose PW, Bron AJ. Economic and quality-of-life impact of seasonal allergic conjunctivitis in Oxfordshire. Neuro-Ophthalmology. 2004;11:17-33.

20. Bielory L. Ocular allergy overview. Immunol Allergy Clin North Am. 2008:28:1-23.

21. Bielory L, Dinowitz M, Rescigno R. Ocular allergic diseases: Differential diagnosis, examination techniques and testing. J Cutan Ocular Toxicol. 2002;21:329-51.

22. Palmares J, Delgado L, Cidade M, Quadrado M, Filipe H. Allergic conjunctivitis: a national cross-sectional study of clinical characteristics and quality of life. Eur J Ophthalmol. 2010;20:257-64.

23. Geraldini M, Neto HJC, Riedi CA, Rosario N. Conjunctivitis: 359 prevalence of allergic conjunctivitis in childhood. World Allergy Organ J. 2012;5 Suppl 2:S132.

24. Glaucoma Research Foundation. Glaucoma facts and stats, 2012. www. glaucoma.org. Accessed 11 Sept 2013

25. Asiedu K, Kyei S, Boampong F, Ocansey S. Symptomatic Dry Eye and Its Associated Factors: A Study of University Undergraduate Students in Ghana. Eye Contact Lens. 2016 [Epub ahead of print]

26. Mansouri K, Orgul S, Meier-Gibbons F, Mermoud A. Awareness about glaucoma and related eye health attitudes in Switzerland: a survey of the general public. Ophthalmologica. 2006;220:101-8.
27. Pfeiffer N, Krieglstein GK, Wellek S. Knowledge about glaucoma in the unselected population: A German survey. J Glaucoma. 2002:11:458-63.

28. Altangerel U, Nallamshetty HS, Uhler T, Fontanarosa J, Steinmann WC, Almodin JM, et al. Knowledge about glaucoma and barriers to follow-up care in a community glaucoma screening programme. Can J Ophthalmol. 2009;44:66-9.

29. Lau JTF, Lee V, Fan D, Lau M, Michon J. Knowledge about cataract, glaucoma, and age related macular degeneration in the Hong Kong Chinese population. Br J Ophthalmol. 2002:86:1080-4.

30. Michielutte R, Diseker RA, Stafford CL, Carr P. Knowledge of diabetes and glaucoma in a rural North Carolina community. J Comm Health. 1984;9:269-84.

31. Dandona R, Dandona L, John RK, McCarty CA, Rao GN. Awareness of eye diseases in an urban population in southern India. Bull World Health Org. 2001;79:96-102.

32. Krishnaiah S, Kovai V, Srinivas M, Shamanna BR, Rao GN, Thomas R. Awareness of glaucoma in the rural population of Southern India. Ind J Ophthalmol. 2005;53:205-8.

33. Sathyamangalam RV, Paul PG, Ronnie G, Baskaran M, Hemamalini A, Raj VM, et al. Determinants of glaucoma awareness and knowledge in urban Chennai. Ind J Ophthalmol. 2009:57:355-60.

34. Tenkir A, Solomon B, Deribew A. Glaucoma awareness among people attending ophthalmic outreach services in South Western Ethiopia. BMC Ophthalmol. 2010;10:17.

35. Onunkwur, Cl. Assessment of knowledge about glaucoma amongst patients attending an eye clinic in Abuja, Nigeria, University of South Africa, Pretoria. 2010. http://hdl.handle.net/10500/4924. Accessed 11 Mar 2013.

36. Obeng BB, Amoah AS, Larbi IA, Yazdanbakhsh M, Van Ree R, Boakye DA, et al. Food allergy in Ghanaian schoolchildren: data on sensitization and reported food allergy. Int Arch Allergy Immunol. 2011;155:63-73.

37. Melton R, Thomas RK, Bartlett JD, Bielory L, Meltzer EO, Nichols KK. Pharmacologic Management of Allergic Conjunctivitis: An Evidence-Based Algorithm. Report of the Ad Hoc Committee for the Pharmacologic Management of Allergic Conjunctivitis. Bausch \& Lomb Incorporated, 2013. US/BEP/13/002

38. Foster A, Resnikoff S. The impact of Vision 2020 on global blindness. Eye. 2005;19:1133-5

39. Bielory L. Ocular allergy. Mt Sinai J Med. 2011;78:740-58.

40. Uhr JH, Mishra K, Wei C, Wu AY. Awareness and knowledge of emergent ophthalmic disease among Patients in an Internal Medicine Clinic. JAMA Ophthalmol. 2016;134:424-31.

41. Amu EO, Adegun PT. Awareness and knowledge of Sexually Transmitted Infections among secondary school adolescents in Ado Ekiti, South Western Nigeria. Journal of Sexually Transmitted Diseases. 2015, Article ID 260126. doi:10.1155/2015/260126

42. Kayar NB, Doğan FG, Ozdemir T, Dalkıran SB, Gül F, Gözütok V, et al. Awareness and knowledge of patients with acute coronary syndromes about coronary artery disease. J Am Coll Cardiol. 2013;62(18_S2):C49.

43. Asiedu K, Kyei S, Agyeman FO, Gyamfi KM. Self medication with over-thecounter topical ophthalmic medications: a study of undergraduates in Ghana. Indo Global Journal of Pharmaceutical Sciences. 2016:6:34-7.

44. Kyei S, Ocansey S, Abu EK, Gyedu BN. Appraisal of the practice of ocular selfmedication in Cape Coast Metropolis, Ghana. Optometry Reports. 2014;4:2164.

45. Wiler J. Symptoms: Severe Eye Pain, Photophobia, Burning, Tearing. Emergency Medicine News. 2011;33:13-4.

46. Amoah AS, Obeng BB, Larbi IA, Versteeg SA, Aryeetey $Y$, Akkerdaas JH, et al. Peanut-specific IgE antibodies in asymptomatic Ghanaian children possibly caused by carbohydrate determinant cross-reactivity. J Allergy Clin Immunol. 2013;132:639-47

47. Caraballo L, Zakzuk J, Lee BW, Acevedo N, Soh JY, Sánchez-Borges M, et al. Particularities of allergy in the Tropics. World Allergy Organ J. 2016;9(20):1-44

48. Abokyi S, Koffuor GA, Kyei S, Asiamah EA, Atobiga CN, Awuah A. Antiallergic effect of an aqueous leaf extract of Pistia stratiotes in murine model of ovalbumin-induced allergic conjunctivitis. Pharmacognosy Res. 2014;6:274-9.

49. Boadi-Kusi SB, Kyei S, Mashige KP, Hansraj R, Abraham CH, Ocansey S, Agbedzie EL. Awareness, knowledge and self-care practices toward glaucoma among final year health science university students in Ghana. Clin Exp Optom. 2015;98:160-7 